\title{
Impact of sociodemographic factors on the consumption of tubers in Brazil
}

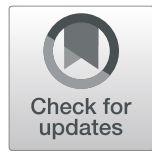

Justyna Horodyska', Sandrine Pigat ${ }^{1 *}$, Jasmin Wonik' ${ }^{1}$ Foteini Bompola ${ }^{1}$, David Cai ${ }^{2}$, Colin D. Rehm ${ }^{3}$ and

Tanhia D. Gonzalez ${ }^{2}$

\begin{abstract}
Background: Although tubers play a significant role in Brazilian agriculture, very little is known about the intake of tubers among the Brazilian population. The objective of this study was to characterize the intake of tubers across Brazil. The types of tubers consumed were quantified, and the impact of geographic and sociodemographic factors was assessed.
\end{abstract}

Methods: This cross-sectional study is based on dietary intake data of 33,504 subjects obtained from the Brazilian National Dietary Survey. All tuber containing foods were identified, and the contribution of different tubers to overall tuber consumption in Brazil was quantified. Descriptive analyses assessed the impact of macroregion and sociodemographic characteristics on tuber consumption, and differences in intake were assessed using statistical tests. Lastly, the dietary intakes of tuber consumers and non-consumers were compared after adjusting for energy and covariates to determine if there were any major differences in dietary intakes between the two groups.

Results: Fifty-five percent of the Brazilian population consumed tubers, which differed by macroregion. The intake of tubers among consumers also differed between macroregions. Overall, rural areas reported significantly higher mean daily intakes of tubers (122 g/day) among tuber consumers than urban areas ( $95 \mathrm{~g} /$ day). Mandioca and potato were the most commonly consumed tubers (59 and 43\% prevalence, respectively, on any of the 2 days), while the highest daily intakes amongst tuber consumers across Brazil were noted for sweet potato (156 g/day) and potato ( $95 \mathrm{~g} /$ day). On a macroregion level, among tuber consumers, mandioca had the highest prevalence of consumption in the North (94\%), Northeast (83\%), and Central-West (68\%), while consumption of potatoes was most prevalent in the Southeast (63\%) and South (62\%). Compared to women, small but significantly higher tuber intakes were noted for males (108 vs. $85 \mathrm{~g} /$ day). There were no significant differences in intakes among income quintiles. After adjusting for energy and other covariates, nutrient intakes between tuber and non-tuber consumers were not meaningfully different, with the exception of sodium ( $+6.0 \%$ comparing non-tuber to tuber consumers), iron (+ 6.1\%), zinc (+ 5.7\%), vitamin C (+ 8.3\%), riboflavin (+ 9.0\%), and folate $(+7.9 \%)$.

Conclusions: Tuber consumption is influenced by regional and sociodemographic characteristics of the Brazilian population. When looking at energy-adjusted nutrient intakes, diets of tuber consumers have resulted in somewhat lower intakes of some micronutrients, namely riboflavin, folate, vitamin C, iron, sodium, and zinc.

Keywords: Dietary survey, BNDS, Intake, Vegetable, Mandioca, Cassava, Yam, Carrot, Potato, Sweet potato, Beet

\footnotetext{
* Correspondence: sandrine.pigat@cremeglobal.com

${ }^{1}$ Creme Global Ltd, Dublin, Ireland

Full list of author information is available at the end of the article
}

(c) The Author(s). 2021 Open Access This article is licensed under a Creative Commons Attribution 4.0 International License, which permits use, sharing, adaptation, distribution and reproduction in any medium or format, as long as you give appropriate credit to the original author(s) and the source, provide a link to the Creative Commons licence, and indicate if changes were made. The images or other third party material in this article are included in the article's Creative Commons licence, unless indicated otherwise in a credit line to the material. If material is not included in the article's Creative Commons licence and your intended use is not permitted by statutory regulation or exceeds the permitted use, you will need to obtain permission directly from the copyright holder. To view a copy of this licence, visit http://creativecommons.org/licenses/by/4.0/ The Creative Commons Public Domain Dedication waiver (http://creativecommons.org/publicdomain/zero/1.0/) applies to the data made available in this article, unless otherwise stated in a credit line to the data. 


\section{Introduction}

Tubers play a significant role in Brazilian agriculture. The average per capita amount of roots and tubers produced in Brazil is $288 \mathrm{~g} /$ capita/day [1], potatoes, cassava, sweet potatoes, and yams being the main tuber crops grown in Brazil. Tubers are also an important part of the Brazilian diet and are often consumed as a side dish or bread substitute using tapioca. Cassava, also known as mandioca, is an important crop in Brazil, and it is often consumed whole, as part of cooked stews, and in the form of grits or flour, as a side dish [2]. Cassava flour is incorporated into traditional Brazilian dishes such as 'Farofa' and 'Tutu de Feijao,' while Cassava starch is used for making a traditional dish called 'Pao de Queijo.'

Roots and tubers are primarily composed of water, carbohydrates, and low levels of protein and fat. The main carbohydrate found in tuber crops is starch. Polysaccharides that constitute the fiber component of roots and tubers include cellulose, hemicellulose, pectin, and resistant starch. When consumed with skin, potatoes and sweet potatoes can provide $2.1 \mathrm{~g} / 100 \mathrm{~g}$ and $3.3 \mathrm{~g} / 100 \mathrm{~g}$ of dietary fiber, respectively. Cooking with subsequent cooling of potatoes has shown to double their total amount of resistant starch [3]. Potatoes are a good source of Vitamin C (15\% DV/110 g) and Vitamin $\mathrm{B}_{6}(13 \% \mathrm{DV} / 110 \mathrm{~g})$, while sweet potatoes are an excellent source of Vitamin A (>127\% DV/110 g) as well as a good source of Vitamin $B_{5}$ and $B_{6}$ (12\% DV/110 g and $11 \% \mathrm{DV} / 110 \mathrm{~g}$, respectively). Yams, also known in Brazil as inhame, are a good source of Vitamin C (15\% DV/110 g).

Although Brazil has been a large vegetable producer, with $40 \%$ of the production being roots and tubers, very little is known about the intake of tubers among the Brazilian population $[4,5]$. The objective of this study was to characterize tuber consumption across all macroregions of Brazil.

\section{Materials and methods \\ Data preparation and subjects}

This study was based on the Brazilian National Dietary Survey (BNDS), which is a two-day non-consecutive 24$h$ record (including weekend days) of food and beverage consumption carried out by the Brazilian Institute of Geography and Statistics (IBGE) as part of the 20082009 Household Budget Survey. Briefly, participants provided all foods and beverages, including the time and place of eating occasions and cooking methods. Quality control was carried out by the interviewers while collecting data, and the data were entered into software developed by IBGE [4]. For the purpose of this study, 33,504 subjects between the ages of 10-104 years old (inclusive) with data necessary for the creation of survey weights were selected. A subset of this cohort, including only those who consumed one or more tuber containing foods/beverages on one or two of their recall days (i.e., tuber consumers), was created $(n=18,901)$. Other than their ages and survey weights, the following variables were collected: urban vs. rural residence, the region of residence, monthly household income, and sex.

\section{Food categorization}

The dietary records were available for every subject in BNDS, which listed foods by name and the quantity consumed. The nutritional information for each food and beverage consumed was also available in BNDS. Foods consumed in the survey were identified from their names only as containing mandioca, yam, carrot, potato, beet, and sweet potato, which will be referred to herein as tuber types and collectively, tubers. From the 1971 unique foods in the BNDS, 162 foods were deemed to include tubers in-part or in-whole and different levels of processing (e.g. cooked cassava, cassava cake or Tapioca pudding) (Table S1). To account for the tuber part only within a composite dish consumed, information regarding the fraction of tuber was sourced from equivalent dishes/recipes from the United States Department of Agriculture What We Eat in America Food Commodity Intake Database 2005-10 (WWEIA-FCID, http://fcid. foodrisk.org/recipes/) and were applied (Table S1). For foods in BNDS for which no equivalents were available in the FCID, online research for recipes and Brazilian supermarket information was used to estimate a fraction. Where two or more different tubers were found to be part of a single food, each relevant fraction of the food was listed in the appropriate category. The methods of preparation/processing of the tuber portion of the food were also estimated from the food name only. These categories were tuber juice, tuber starch, whole tuber, whole tuber flour, a by-product of tuber processing and not applicable (uncategorized).

\section{Intake assessments}

Nutrient intakes from each eating event were calculated as follows: the weight of food/beverage consumed in each eating event multiplied by nutrient concentration in that food/beverage. They were then summed up per person, per day, per nutrient. These values were divided by the number of consumption days to get an average daily nutrient intake over the two-day survey period per person. Where a given tuber type did not represent the entire food, only the fraction of the food which had been assigned to that tuber type was considered. However, the nutrient content of the complete dish (accounting for food ingredients other than tubers) was considered when calculating nutrient intakes. A total population's tuber consumption and daily nutrient intake were represented to account for the survey weightings. The population's consumption of each tuber type by weight $(\mathrm{g})$ and 
nutrient intakes from the eating events was expressed as distributions using a Monte-Carlo simulation-based dietary exposure model [6] in Expert Models Food Data Science (Creme Global, Dublin, Ireland; accessed October 2017).

\section{Statistical analyses}

Brazil is divided into five macroregions by the Brazilian Institute of Geography and Statistics (IBGE): North (7 states, largest metropolitan area Manaus), Northeast (9 states, Recife), Central-West (3 states. Brasilia), Southeast (4 states, Sao Paulo), and South (3 states, Porto Alegre). In this study, an analysis of variance (ANOVA) test was conducted to determine significant differences $(P<$ 0.01 ) in the consumption of tubers and tuber types between rural and urban areas within Brazil. Furthermore multiple regression analysis was conducted to determine significant differences $(P<0.05)$ in the consumption of tubers and tuber types across the five Brazilian macroregions, as well as rural and urban areas within the macroregions. Multiple regression was also carried out to evaluate associations between tuber consumption and gender/age/income groups of the consumers across Brazil. Associations between the groups were deemed statistically significant at a $P<0.05$. Post hoc Tukey test was performed to determine which pairs of the regional and sociodemographic group means were significantly different. Nutrient analysis was carried out in a regression model with adjustments for age, gender, region, rural/urban area, and income. Differences in mean intakes (g/day) normalized by energy ( $\mathrm{kcal} /$ day) between tuber consumers and non-tuber consumers across Brazil were considered significant at a $P<0.01$. All statistical analyses were performed using $\mathrm{R}$ (version 3.5.2, https:// www.r-project.org) and Python (version 3.7.7, http:// www.python.org).

\section{Results}

The intake of tubers among tuber consumers in rural and urban areas across the five Brazilian macroregions is presented in Table 1. Fifty-five percent (18,901 people) of the total Brazilian population consumed at least one tuber containing food during the two-day survey period. Across all Brazil, rural and urban areas contained 58 and 54\% tuber consumers, respectively. Tuber consumers in rural areas across Brazil ate significantly more tubers (mean: $122 \mathrm{~g} /$ day) as part of their diets than those in urban areas (mean: $95 \mathrm{~g} /$ day). Fifty-one percent of people in the Southeast consumed tubers compared to $55 \%$ in the Northeast macroregion. Of all macroregions, the highest tuber consumption among tuber consumers was noted in the South (mean: $112 \mathrm{~g} /$ day), followed by the North (mean: $107 \mathrm{~g} /$ day). Tuber intakes in these regions were significantly $(P<0.05)$ higher than in the Southeast and Central-West.
The lowest intakes of tubers across all macroregions were found in the Central-West (mean: $91 \mathrm{~g} /$ day) and the Northeast ( $99 \mathrm{~g} /$ day). The tuber consumption in these regions was significantly $(P<0.05)$ lower than in the North and South. Differences in the tuber intakes between urban and rural areas were found across all macroregions, with significantly higher $(\mathrm{P}<0.05)$ intakes noted in rural areas. Specifically, the North rural area consumed the highest amounts of tubers (mean: $149 \mathrm{~g} /$ day), while the CentralWest urban area consumed the lowest amounts of tubers (mean: $85 \mathrm{~g} /$ day).

Differences in mean consumption between genders and age groups across all tuber consumers in Brazil were observed. Male consumers were significantly $(P<0.05)$ associated with increased intake of tubers. In relation to age there were no significantly different intakes observed. Differences in mean intakes between income groups across all tuber consumers in Brazil were not foundbut intakes tended to be higher in the lower income quintiles (the first quintile being lowest vs. fifth quintile being highest income group).

The intake of specific tuber types among tuber consumers in rural and urban areas across all Brazilian macroregions is shown in Table 2. Mandioca and potato were the most prevalent tubers in Brazil (59 and 43\%, respectively). Consumption of mandioca was more prevalent amongst consumers in rural than in urban areas (76 and 55\%, respectively). There were twice as many potato consumers in urban than in rural areas (47 and $24 \%$, respectively). Sweet potato and yam were the least commonly consumed tubers in Brazil (3.8 and $3.5 \%$, respectively). Sweet potato consumption was lower in urban areas than in rural areas (3.3 and 6.2\%, respectively), while yams consumption was less disparate (3.3 and $3.5 \%$, respectively). However, among consumers of each type, the highest daily intake across all of Brazil was noted for sweet potato, followed by potato and yam (mean: 156, 95, and 84 g/day, respectively).

On a macroregion level, the most commonly consumed tubers in the Northeast were mandioca (83\%), potato $(16 \%)$, and sweet potato $(8 \%)$, while in the Southeast, the most popular tubers were potato $(63 \%)$, mandioca (42\%) and carrot (15\%). The most commonly consumed tubers in the South, which is the third most populated region concentrating 15\% of the Brazilian population [7], were potato (62\%), mandioca (34\%), and carrot $(21 \%)$. The highest intakes of mandioca (mean: $101 \mathrm{~g} /$ day) were observed in the North, while the highest intakes of potato were noted in the South (mean: 104 g/ day). For sweet potato and beet, the highest consumption was found in the Northeast (mean:172 and $92 \mathrm{~g} /$ day, respectively). Lastly, the highest intakes of carrot were observed in the Southeast (mean: $30 \mathrm{~g} /$ day). Concerning differences in the consumption of tuber types among 
Table 1 Intake of tubers in Brazil according to regional and sociodemographic characteristics

\begin{tabular}{|c|c|c|c|c|c|}
\hline \multirow[t]{2}{*}{ Regions } & \multirow{2}{*}{$\begin{array}{l}\text { Number of } \\
\text { Tuber } \\
\text { Consumers }\end{array}$} & \multicolumn{3}{|c|}{ Intake by Tuber Consumers (g/day) } & \multirow{2}{*}{$\begin{array}{l}\text { Prevalence } \\
\text { of tuber } \\
\text { consumers } \\
\text { (\%) }\end{array}$} \\
\hline & & Median & Mean & SD & \\
\hline All Brazil & 18,901 & 78 & 101 & 102 & 54.7 \\
\hline Female & 10,070 & 72 & $95^{\mathrm{b}}$ & 93 & 54.7 \\
\hline Male & 8831 & 80 & $108^{\mathrm{a}}$ & 110 & 54.7 \\
\hline 10-12 years & 1182 & 66 & $91^{\mathrm{b}}$ & 103 & 54.1 \\
\hline $13-18$ years & 2415 & 72 & $97^{\mathrm{b}}$ & 107 & 50.7 \\
\hline 19-34 years & 6073 & 80 & $104^{\mathrm{b}}$ & 103 & 54.2 \\
\hline $35-49$ years & 4646 & 80 & $103^{\mathrm{b}}$ & 100 & 57.1 \\
\hline $50-65$ years & 3045 & 75 & $104^{\mathrm{b}}$ & 103 & 56.8 \\
\hline $66+$ years & 1540 & 80 & $100^{\mathrm{b}}$ & 93 & 52.2 \\
\hline Rural & 4807 & 95 & $122^{a}$ & 127 & 58.1 \\
\hline Urban & 14,094 & 74 & $95^{\mathrm{b}}$ & 95 & 54 \\
\hline Income - 1st quintile ${ }^{a}$ & 3251 & 80 & $104^{\mathrm{a}}$ & 110 & 51.7 \\
\hline Income - 2nd quintile ${ }^{a}$ & 3537 & 80 & $107^{\mathrm{a}}$ & 112 & 51.1 \\
\hline Income - 3rd quintile ${ }^{a}$ & 3905 & 80 & $100^{a}$ & 97 & 52.8 \\
\hline Income - 4th quintile ${ }^{a}$ & 4087 & 80 & $105^{a}$ & 110 & 55.9 \\
\hline Income - 5th quintile ${ }^{a}$ & 4121 & 71 & $93^{\mathrm{a}}$ & 87 & 59 \\
\hline North & 3404 & 80 & $107^{\mathrm{b}}$ & 115 & 73.1 \\
\hline Rural & 1137 & 102 & $149^{\mathrm{a}}$ & 154 & 80.3 \\
\hline Urban & 2267 & 71 & $93^{b}$ & 87 & 70.4 \\
\hline Northeast & 6872 & 70 & $99^{\mathrm{b}}$ & 107 & 54.6 \\
\hline Rural & 1737 & 80 & $116^{\mathrm{a}}$ & 130 & 57.7 \\
\hline Urban & 5135 & 66 & $95^{\mathrm{b}}$ & 95 & 53.4 \\
\hline Southeast & 3889 & 80 & $103^{b}$ & 93 & 51.4 \\
\hline Rural & 754 & 95 & $115^{\mathrm{a}}$ & 100 & 48.2 \\
\hline Urban & 3135 & 80 & $96^{b}$ & 92 & 51.7 \\
\hline South & 2332 & 88 & $112^{\mathrm{b}}$ & 105 & 55.8 \\
\hline Rural & 602 & 102 & $132^{a}$ & 112 & 60.5 \\
\hline Urban & 1730 & 84 & $104^{b}$ & 103 & 54.9 \\
\hline Central-West & 2404 & 53 & $91^{\mathrm{b}}$ & 103 & 54.3 \\
\hline Rural & 577 & 80 & $115^{\mathrm{a}}$ & 121 & 46.1 \\
\hline Urban & 1827 & 51 & $85^{\mathrm{b}}$ & 101 & 55.4 \\
\hline
\end{tabular}

Means were adjusted for age, gender, region, rural/urban area, and income. Means that do not share the same letter are significantly different $(p<0.05)$ to each other; SE: standard deviation; ${ }^{a}$ Household monthly income (R\$)

tuber consumers in rural and urban areas (Table 2), statistical analysis revealed that increased mandioca consumption was significantly $(P<0.05)$ associated with rural areas across all five macroregions. Moreover, potato intakes in the North rural area were significantly $(\mathrm{P}<0.05)$ higher than those in the urban areas.

Regional differences in the preparation methods of tubers are shown in Fig. 1. This analysis aimed to explore tuber consumption habits in terms of the preparation methods amongst consumers living across the Brazilian macroregions. Mandioca was consumed in cooked dishes either whole and in the form of flour or starch, with the highest proportion of mandioca flour being consumed in the North, followed by Northeast and Southeast. Potato, sweet potato, and yam were consumed in dishes that incorporate the whole tuber across all five macroregions. Beet was consumed whole and as a juice, with the highest proportion of juice being in the Northeast region, followed by North and Central-West. While carrot was primarily consumed as a whole, a small proportion of juice consumption was observed in the Northeast, Southeast, South, and Central-West. 


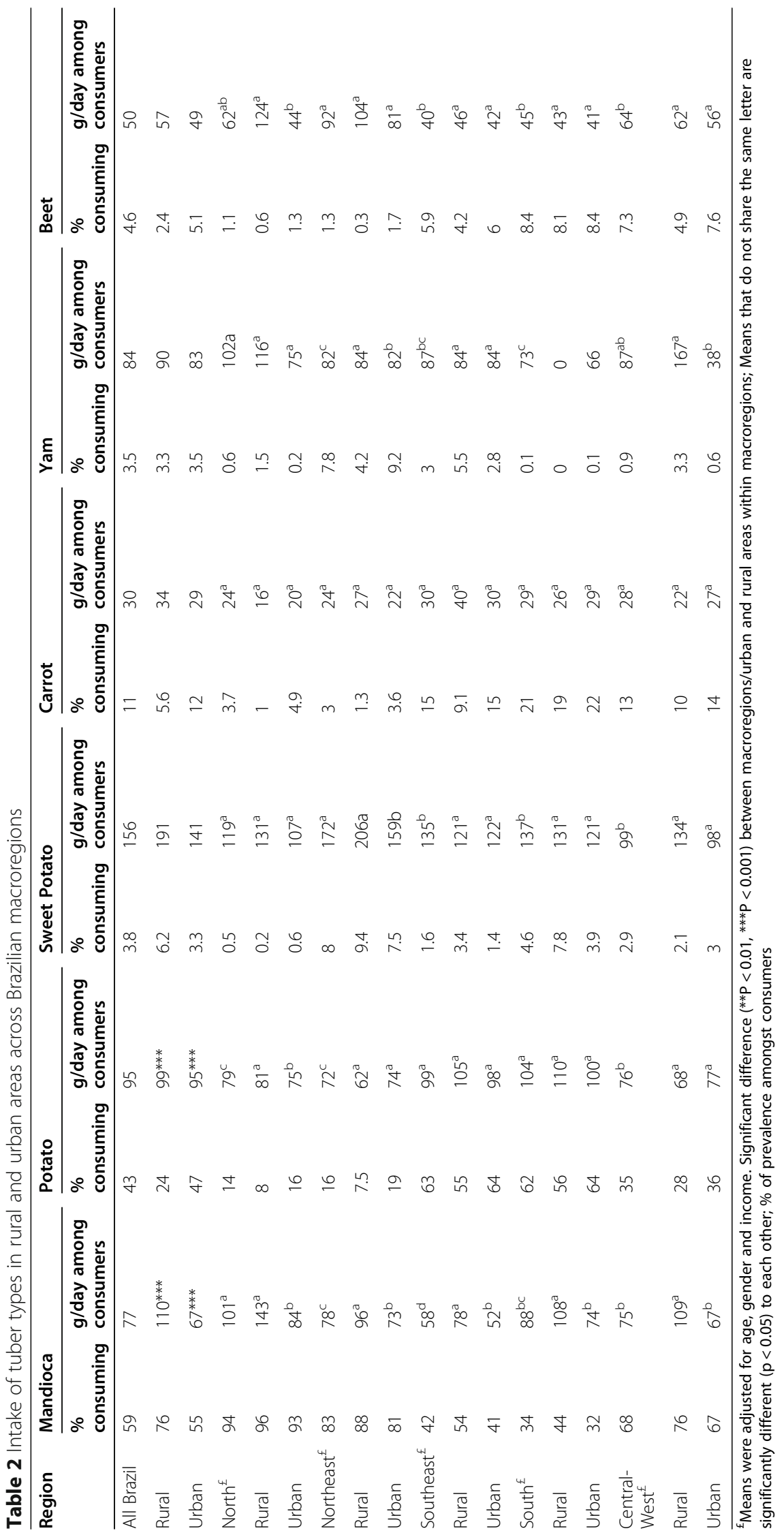




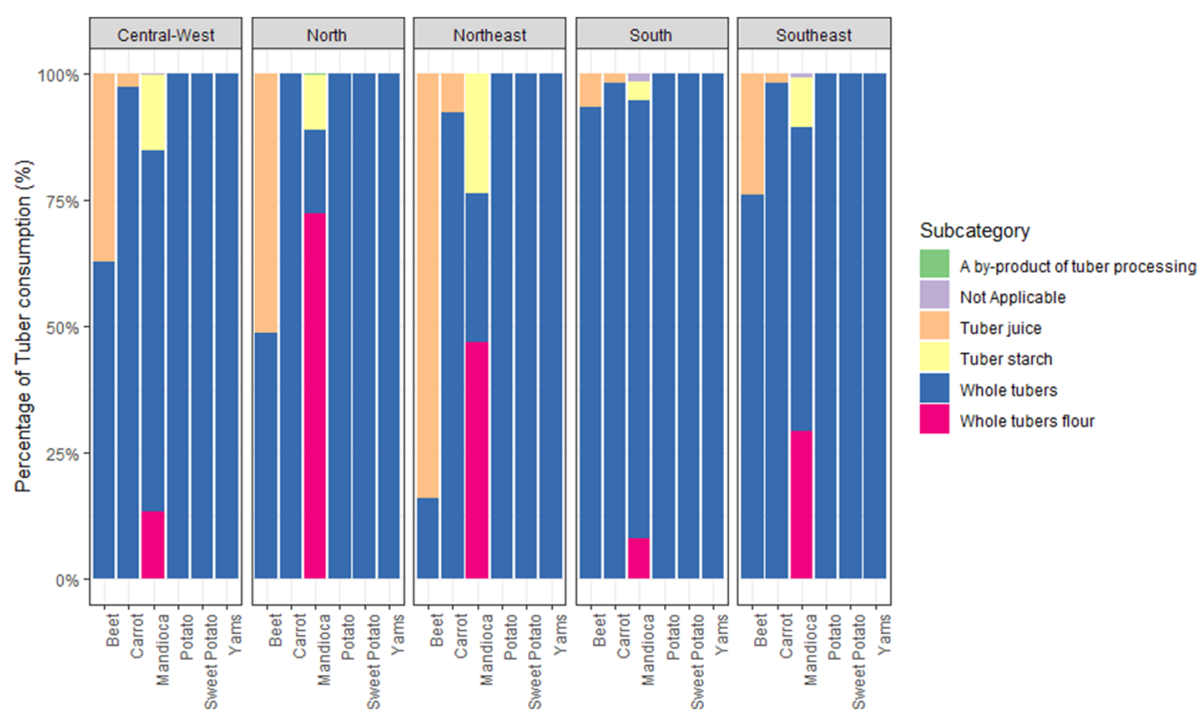

Fig. 1 Percentage of tuber consumption per processing type across the five Brazilian macroregions

Nutrient intake of tuber consumers and non-tuber consumers across Brazil is shown in Table 3. Differences in energy intake $(\mathrm{kcal} /$ day $)$ were significantly $(P<0.001)$ associated with tuber consumption, where individuals that consumed tubers had 16\% higher energy intake per day when compared to non-tuber consumers. The regression analysis adjusted by sociodemographic variables also identified small but significant differences among tuber and non-tuber consumers in nutrients intakes.

The diet of those who include tubers contained higher intakes of all macronutrients (protein, carbohydrates, fiber, and fat). The macronutrient differences were mostly attributed to higher energy intake. Among tuber consumers, the energy-adjusted mean protein intake was $4 \%$ lower $(P<0.001)$, while the consumption of carbohydrates and fiber was 2 and $0.6 \%$ higher $(\mathrm{P}<0.001)$ compared to non-consumers. There was no statistically significant difference in energy-adjusted fat intakes between both consumer types. The micronutrient density of the tuber containing diet was significantly $(P<0.01)$ altered within the Brazilian population, apart from magnesium, copper, retinol, niacin, and alpha-tocopherol remaining unchanged $(P<0.1)$. In particular, the tuber containing diet was found to be less dense in terms of riboflavin (9\%), folate (8\%), vitamin C (8\%), iron (6\%), sodium (6\%), and zinc (6\%) when compared to the diet of non-tuber consumers.

\section{Discussion}

In this study, we investigated the intake of tubers and the prevalence among tuber consumers in rural and urban areas across the five Brazilian macroregions. The percentage of tuber consumption per processing type across the Brazilian macroregions was also examined.
Moreover, this study assessed the differences in tuber consumption between genders and age groups and energy and nutrient intake of tuber consumers versus nontuber consumers across all Brazil. This study has shown that the prevalence and intake of tubers amongst tuber consumers differed between macroregions, with rural areas having significantly higher mean daily intakes of tubers than urban areas. Compared to women, small but significantly higher tuber intakes were noted for males. There was no significant difference between consumption of tubers among income quintiles. Nutrient intakes between tuber and non-tuber consumers were non meaningfully different, with a few exceptions.

\section{Tuber consumption across Brazilian macroregions}

This study has shown that $55 \%$ of the Brazilian population consumed tubers at least on 1 day over the two-day survey. A previous study reported the highest consumption of roots and tubers in rural areas in the South, Southeast, and Central-West [8]. Although the North's and Northeast's consumption was well below the national average, rural areas exhibited higher consumption, with some areas meeting or exceeding the national average [8]. This study shows a higher intake of tubers among tuber consumers in rural areas for all five macroregions. The rural area in the North consumed the largest amounts of tubers. The highest consumption of tubers observed in the North's rural area might be related to mandioca's highest consumption in that region. In turn, the highest intake of mandioca in the North may be explained by the fact that the North is the largest producer of roots and tubers, of which $87 \%$ is mandioca [1].

Mandioca and potato were the most commonly consumed tubers across all Brazil, while the highest daily 
Table 3 Nutrient intake of tuber consumers and non-tuber consumers across Brazil

\begin{tabular}{|c|c|c|c|}
\hline \multirow[t]{2}{*}{ Nutrient (unit) } & \multicolumn{2}{|l|}{ Mean Intakes (SE) } & \multirow[t]{2}{*}{$\Delta$ Mean Intakes (\%) } \\
\hline & $\begin{array}{l}\text { Tuber Consumers } \\
\mathrm{N}=18,901\end{array}$ & $\begin{array}{l}\text { Non-Tuber Consumers } \\
N=14,603\end{array}$ & \\
\hline Energy (kcal/day) & $1848(0.003)$ & $1600(0.003)$ & $248(15.5)^{* * *}$ \\
\hline \multicolumn{4}{|l|}{ Macronutrients } \\
\hline Protein (g/day) & $83.3(0.003)$ & $75.5(0.004)$ & $7.8(10.3)^{* * *}$ \\
\hline Protein (g/1000 kcal) & $45.4(0.002)$ & $47.4(0.002)$ & $2(4.2)^{* * *}$ \\
\hline Total Fat (g/day) & $57.5(0.004)$ & $50.1(0.004)$ & $7.4(14.8)^{* * *}$ \\
\hline Total Fat (g/1000 kcal) & $30.8(0.002)$ & $30.9(0.002)$ & $0.09(0.3)$ \\
\hline Carbohydrates (g/day) & $247(0.003)$ & $209(0.003)$ & $37.2(17.7)^{* * * *}$ \\
\hline Carbohydrates (g/1000 kcal) & $134(0.001)$ & $132(0.001)$ & $2.3(1.7)^{* * *}$ \\
\hline Total Fiber (g/day) & $21.1(0.004)$ & $18.4(0.004)$ & $2.7(14.6)^{* * *}$ \\
\hline Total Fiber (g/1000 kcal) & $11.7(0.003)$ & $11.8(0.003)$ & $0.07(0.6)^{* * *}$ \\
\hline \multicolumn{4}{|l|}{ Micronutrients } \\
\hline Calcium (mg/1000 kcal) & $277(0.004)$ & $285(0.004)$ & $8.3(2.9)^{* * *}$ \\
\hline Magnesium (mg/1000 kcal) & $139(0.002)$ & $140(0.003)$ & $0.7(0.5)$ \\
\hline Manganese (mg/1000 kcal) & $2.94(0.030)$ & $3.06(0.034)$ & $0.12(3.8)^{* *}$ \\
\hline Phosphorus (mg/1000 kcal) & $551(0.002)$ & $563(0.002)$ & $12.8(2.3)^{* * *}$ \\
\hline Iron (mg/1000 kcal) & $6.27(0.002)$ & $6.68(0.003)$ & $0.41(6.1)^{* * *}$ \\
\hline Sodium (g/1000 kcal) & $0.83(0.005)$ & $0.89(0.005)$ & $0.05(6)^{* * *}$ \\
\hline Potassium (mg/1000 kcal) & $1357(0.002)$ & $1339(0.002)$ & $17.9(1.3)^{* * *}$ \\
\hline Copper (mg/1000 kcal) & $0.75(0.012)$ & $0.73(0.013)$ & $0.01(2)$ \\
\hline Zinc (mg/1000 kcal) & $6.18(0.003)$ & $6.56(0.003)$ & $0.37(5.7)^{* * *}$ \\
\hline Selenium ( $\mu \mathrm{g} / 1000 \mathrm{kcal})$ & $50.7(0.004)$ & $51.6(0.005)$ & $0.88(1.7)^{* *}$ \\
\hline Retinol ( $\mu \mathrm{g} / 1000 \mathrm{kcal})$ & $224(0.026)$ & $215(0.029)$ & $8.3(3.9)$ \\
\hline Thiamin (vitamin B1) (mg/1000 kcal) & $0.64(0.002)$ & $0.67(0.002)$ & $0.03(3.9)^{* * *}$ \\
\hline Riboflavin (vitamin B2) (mg/1000 kcal) & $0.89(0.003)$ & $0.97(0.003)$ & $0.09(9)^{* * *}$ \\
\hline Niacin (vitamin B3) (mg/1000 kcal) & $8.31(0.003)$ & $8.44(0.004)$ & $0.13(1.5)$ \\
\hline Pyridoxine (vitamin B6) (mg/1000 kcal) & $0.84(0.002)$ & $0.83(0.003)$ & $0.01(1.1)^{* * *}$ \\
\hline Cobalamine (vitamin B12) ( $\mu \mathrm{g} / 1000 \mathrm{kcal})$ & $3.23(0.015)$ & $3.14(0.017)$ & $0.09(2.7)^{* *}$ \\
\hline Folate (dietary equivalent) $(\mu \mathrm{g} / 1000 \mathrm{kcal})$ & $149(0.004)$ & $162(0.004)$ & $12.8(7.9)^{* * *}$ \\
\hline Vitamin D (calciferol) ( $\mu \mathrm{g} / 1000 \mathrm{kcal})$ & $1.91(0.008)$ & $1.96(0.009)$ & $0.05(2.8)^{* * *}$ \\
\hline Vitamin E (total Alpha-tocopherol) (mg/1000 kcal) & $2.28(0.003)$ & $2.27(0.003)$ & $0.01(0.5)$ \\
\hline Vitamin C (mg/1000 kcal) & $100(0.027)$ & $109(0.031)$ & $9(8.3)^{* *}$ \\
\hline
\end{tabular}

Means were adjusted for age, gender, region, rural/urban area, and income; ${ }^{* *} P<0.01$, ${ }^{* *} P<0.001$; SE: standard error; Absolute $\Delta$ (Difference) Mean Intakes = | Tuber Consumers - Non-Tuber Consumers $\mid$ (\% Difference)

intakes among tuber consumers were noted for sweet potato and potato. Interestingly, on a macroregion level, the highest prevalence and consumption for sweet potato and potato were observed amongst consumers living in the Northeast and South and the South and Southeast, respectively. The South and Northeast macroregions are the largest sweet potato producers [5], whereby potato production is concentrated in the South and Southeast $[9,10]$. The highest intake of mandioca was observed in the North. As discussed earlier, this may be supported by the fact that the North is the largest producer of roots and tubers, of which $87 \%$ of the production is mandioca [1].

Mandioca is the most versatile among all tubers consumed in Brazil, and it is incorporated into dishes either cooked whole, in the form of flour, or as refined starch. Typical cooking processes for the whole mandioca include boiling, frying, and roasting. 'Farinha' de Mandioca (also referred to as mandioca flour or cassava flour) is an ingredient used to prepare traditional Brazilian dishes such as 'Farofa' and 'Tutu de Feijao.' Tapioca starch (also called mandioca starch) is a pre-cooked cassava starch 
with a pearl-like appearance. It is used for making traditional dishes such as 'Pao de Queijo,' 'Biscoito de Polvilho,' and 'Brazilian Tapioca' (crepes) [11-13]. Potato, sweet potato, and yam are other tuber types available on the Brazilian markets for consumption in their whole form [14]. Starch produced from these tubers is not as popular as the starch made from mandioca [15]. This is in parallel with our findings showing that potato, sweet potato, and yam were incorporated into dishes as a whole across all five macroregions. Beet can be consumed as a whole vegetable, juice, chips, and powder [15]. In this study, beet was consumed in dishes either whole or as a juice across all macroregions. Interestingly, the Northeast, which consumed the largest amounts of beet of all macroregions, was also shown to consume the highest proportion of beet juice, accounting for approximately $85 \%$ of the total beet consumption in this region.

The carrot consumption didn't significantly differ across the macroregions and no significant intake differences were observed between urban and rural areas. Nevertheless, a higher prevalence of carrot consumers was noted amongst individuals living in urban areas, with the South, Southeast, and Central-West having the highest scores. Only a small proportion of the carrot produced in Brazil is devoted to processing, i.e., juices, meaning that almost all of the harvest is designated for the fresh market [16]. Not surprisingly, carrots were primarily consumed whole as part of mixed dishes across all of Brazil. Moreover, with the rising awareness of healthy food choices, consumers' interest in fresh-cut, minimally processed, and ready to eat vegetables is increasing, i.e., the Brazilian mini-carrots, 'Cenourete' (shape of a mini carrot root) and 'Catetinho' (shape of a small sphere), which can be consumed raw or cooked [16].

\section{Influence of gender, age, and income on tuber consumption}

Male consumers were shown to have higher intakes of tubers than females, although the difference was small. This result is concordant with a previous study demonstrating that men consume more grains, roots, and tubers, and more food in general than women [17]. Concerning the consumers' age influence on tuber intake, the diet of children 10-12 years of age contained fewer tubers. This is not unexpected, as children's total energy requirements are lower than for adults, hence the lower consumption of tubers observed in this age group. Nevertheless, the consumption of fruit and vegetables among Brazilian children is insufficient [18]. Moreover, dietary consumption patterns in children are highly influenced by socioeconomic factors [19]. A study on eating habits during childhood has demonstrated that vegetable consumption increases with age [20]. One reason is that children perceive vegetables to be visually unappealing food [21]. The consumption of tubers amongst individuals aged 13 to $18 \mathrm{did}$ not differ from other age groups. This is surprising as adolescents were shown to consume the largest, although still insufficient, amounts of grains, roots, and tubers [17, 22]. Adolescents require more macronutrients than adults as 15 and $40 \%$ of the adult height and weight, respectively, are gained during this period [23]. Nevertheless, the expected increase in tuber intakes amongst adolescents was not observed in this study. Differences in mean intakes between income groups across all tuber consumers in Brazil were not found, but there was a trend towards higher daily intakes in lower income quintiles. A previous study supports this result, reporting the lowest intake of grains, roots, and tubers by the Brazilian consumers in the top income category (third tertile) [17].

\section{Energy and nutrient intake of tuber consumers}

The present study showed that approximately $52-53 \%$ of the Brazilian diet's energy intake came from carbohydrates, followed by protein (18\%) and fat (12\%). Our results agreed with a previous report estimating that up to $57 \%$ of Brazil's total energy intake was attributed to carbohydrates' consumption [24]. Although Brazil has been a top leader in cassava production, $60 \%$ of Brazil's total carbohydrates intake is coming from rice, beans, bread, coffee, and juices [24]. Our study also found that those who incorporated tubers into their diet consumed $15.5 \%$ more energy than non-tuber consumers. The diet of tuber consumers was characterized by having a higher intake of carbohydrates (17\%), fats (14.8\%), fiber (14.6\%), and protein (10.3\%) than the diet of non-manusscriptuber consumers (Table 3). A previous report estimated that starchy roots and tubers and manioca flour contributed to $13.2 \%$ of the total fiber availability in Brazilian households [25]. After controlling for differences in energy intake and other covariates (Table 3), our findings show that the diet of tuber consuming individuals had $2 \%$ more carbohydrate and $4 \%$ less protein, and the same amount of fat than the diet of non-consumers. Furthermore, a tuber containing diet was less dense in some vitamins (riboflavin, folate, vitamin C) and minerals (iron, sodium, and zinc) compared to the diet of non-tuber consumers. However, the differences tended to be small (e.g., no relative difference was $>10 \%$ ).

\section{Strengths and limitations}

The strength of this present study is that it is based on a large nationally representative survey using a rigorous dietary assessment procedure that can allow for flexible secondary analyses. One of the limitations is that a selfreport dietary measure is subject to random and systematic reporting errors, which may have unpredictable impacts on tuber consumption estimates and other dietary intake measurements. The sample size was also too small to look at smaller geographies as some patterns may have been concealed at the macroregion level. 
Another limitation is that the study focused on nutrients and not dietary patterns/food groups, which are likely of more interest as dietary recommendations have shifted towards greater emphasis on foods as opposed to nutrients. Lastly, at the time of the analysis, this was the most up to date data on food consumption in Brazil; data available through FAOSTAT [26] shows a 30\% decline in the production of cassava between 2010 and 2019 and a large increase $(\approx 62 \%)$ in the production of sweet potatoes during the same period. Lastly, the production of potatoes has almost remained constant between 2010 and 2019. These changes in tuber production may have been driven by consumer demand and may have resulted in changes in the most current amounts and types of tubers consumed by the Brazilian population.

\section{Conclusions}

This study demonstrated that tuber consumption among tuber consumers differed between the Brazilian macroregions, with rural areas having higher intakes than urban. The rural area in the North consumed the largest amounts of tubers, and this may be attributable to the highest production and consumption of mandioca observed in this region. Mandioca is a known staple food in the North and Northeast of Brazil and was consumed as a whole and as flour and starch. Mandioca and potato were the most prevalent amongst tuber consumers across all of Brazil, while the highest intakes among tuber consumers were noted for sweet potato and potato. On a macroregion level, the highest prevalence and consumption for sweet potato and potato were observed amongst consumers living in the Northeast and South (sweet potato) and South and Southeast (potato). These macroregions are the most populated regions concentrating a large proportion of the tuber consumers and are the main producers of these tuber types. Starch produced from potato and sweet potato is not as popular as the starch made from mandioca. This is in parallel with our findings showing that these tuber types were consumed in dishes that incorporated tubers as a whole across all five macroregions. Furthermore, gender and age were shown to influence tuber consumption. A small but significantly higher intake of tubers was noted for male consumers. Tuber consumption resulted in somewhat lower intakes of some micronutrients.

\section{Supplementary Information}

The online version contains supplementary material available at https:/doi. org/10.1186/s12937-021-00709-1

\section{Additional file 1.}

\section{Acknowledgements}

The authors wish to thank Mark Breen (Creme Global), Noel Rogers (Creme Global), and William Goodwin (Creme Global) for performing statistical analyses and Maeve Cushen (Creme Global) for helping with the analysis.

\section{Authors' contributions}

Sandrine Pigat and David Cai are responsible for the initial design and execution of the analysis, Jasmin Wonik and Foteini Bompola carried out the analysis. The study was subsequently refined by Tanhia D. Gonzalez and Colin D. Rehm and carried out by Justyna Horodyska. Justyna Horodyska was responsible for writing the manuscript with additions from Tanhia D. Gonzalez, Sandrine Pigat and Colin D. Rehm. The author(s) read and approved the final manuscript.

\section{Authors' information}

Colin D. Rehm and Tanhia D. Gonzalez are employees of PepsiCo, Inc. David Cai was an employee of PepsiCo, Inc. at the time the study was conducted but is currently not with the company. Sandrine Pigat is an employee of Creme Global Ltd. Justyna Horodyska, Jasmin Wonik and Foteini Bompola were employees of Creme Global Ltd. at the time the study was conducted.

\section{Funding}

This work was funded by PepsiCo, Inc.

Availability of data and materials

Not applicable.

\section{Declarations}

Ethics approval and consent to participate

Not applicable.

Consent for publication

Not applicable.

\section{Competing interests}

The author(s) declare no competing interests. The views expressed in this manuscript are those of the authors and do not necessarily reflect the position or policy of Pepsico, Inc.

\section{Author details}

${ }^{1}$ Creme Global Ltd, Dublin, Ireland. ${ }^{2}$ PepsiCo, Inc., Plano, TX, USA. ${ }^{3}$ PepsiCo, Inc., Purchase, New York, USA.

Received: 5 January 2021 Accepted: 21 May 2021

Published online: 09 June 2021

\section{References}

1. IBGE. 2006 [cited 2020 Apr 1]. Available from: https://www.ibge.gov.br/en/ statistics/economic/agriculture-forestry-and-fishing/17234-census-of-a griculture. html? edicao $=17237 \& \mathrm{t}=$ publicacoes.

2. Visses F, Sentelhas P. Belmont P. Food Security: Yield gap of cassava crop as a measure of food security - an example for the main Brazilian producing regions; 2018

3. Englyst HN, Kingman SM, Cummings JH. Classification and measurement of nutritionally important starch fractions. Eur J Clin Nutr. 1992;46(Suppl 2): S33-50.

4. IBGE, Instituto Brasileiro de Geografi a e Estatística (2010). Consumer Expenditure Survey. https://www.ibge.gov.br/en/statistics/social/popula tion/17387-pof-2008-2009-en.html?edicao=19556\&t=downloads (Accessed 2018-06-18)

5. Jose R, Rayanne M, Luiz A, Aurelio P, Lindomar M, Manoel G, et al. Sweet potato cultivars grown and harvested at different times in semiarid Brazil. Afr J Agric Res. 2016;11:4810-8.

6. McNamara C, Naddy B, Rohan DSJ. Design, development and validation of software for modelling dietary exposure to food chemicals and nutrients. Food Addit Contam. 2003;20:S8-26.

7. Kusek WA, Wise N. Human geography and professional mobility. London: Routledge; 2020.

8. Nolasco CL, Soler LS, Freitas MWD, Lahsen M, Ometto JPHB. Scenarios of vegetable demand vs. production in Brazil: The links between nutritional security and small farming. Land. 2017;6(3):49.

9. Camargo Filho WP, Camargo FP. A quick review of the production and commercialization of the main vegetables in Brazil and the world from 1970 to 2015. Horticultura Brasileira. scielo; 2017. p. 160-6. 
10. da Costa MS, Tonhati R, Neto DD, Darapuneni M, Pavuluri K. Response of tomato to polyhalite as a multi-nutrient fertilizer in Southeast Brazil. J Plant Nutr. 2018;41:2126-40.

11. Lacerda ICA, Miranda RL, Borelli BM, Nunes AC, Nardi RMD, Lachance M-A, et al. Lactic acid bacteria and yeasts associated with spontaneous fermentations during the production of sour cassava starch in Brazil. Int J Food Microbiol. 2005;105:213-9.

12. Chuzel G. The cassava processing industry in Brazil: traditional techniques, technological developments, innovations and new markets. Afr J Food Nutri Security (ISSN: 1608-1366) Vol 1 Num 1. 2001;1.

13. Silva JC, Atroshenko A, Dias De Lima CM, de Almeida RS, de Queiroz Costa $J$ H. Market research regarding manioc flour in Alagoas, Brazil. Novel Res Sci 2(4). 2019; 2(4).

14. Garcia E, Carmo E, Pádua J, Franco C, Leonel M. Potato cultivars as a source of starch in Brazil: physicochemical characteristics of the starches and their correlations. Aust J Crop Sci. 2019:1786-92.

15. Vasconcellos J, Conte-Junior C, Silva D, Pierucci AP, Paschoalin V, Alvares TS. Comparison of total antioxidant potential, and total phenolic, nitrate, sugar, and organic acid contents in beetroot juice, chips, powder, and cooked beetroot. Food Sci Biotechnol. 2016;25:79-84.

16. Lana MM, da Silva JBC, Vieira JV. Cenourete and Catetinho: the mini Brazilian carrots. Horticultura Brasileira. 2001;19(3):376-9.

17. Verly Junior E, Carvalho AM, Fisberg RM, Marchioni DM. Adesão ao guia alimentar Para população Brasileira [adherence to the food guide for the Brazilian population]. Revista de saude publica. 2013;47(6):1021-7.

18. Rieth MA, Moreira MB, Fuchs FD, Moreira LB, Fuchs SC. Fruits and vegetables intake and characteristics associated among adolescents from southern Brazil. Nutr J. 2012;11:95.

19. Santos LP, Assuncao MCF, Matijasevich A, Santos IS, Barros AJD. Dietary intake patterns of children aged 6 years and their association with socioeconomic and demographic characteristics, early feeding practices and body mass index. BMC Public Health. 2016;16:1055.

20. Łuszczki E, Sobek G, Bartosiewicz A, Baran J, Weres A, Dereń K, et al. Analysis of fruit and vegetable consumption by children in school canteens depending on selected sociodemographic factors. Medicina (Kaunas). 2019; 55:397.

21. Chung LMY, Fong SSM. Appearance alteration of fruits and vegetables to increase their appeal to and consumption by school-age children: a pilot study. Health psychology open. SAGE Publications. 2018;5: 2055102918802679.

22. Leal GV da S, Philippi ST, Matsudo SMM, Toassa EC. Food intake and meal patterns of adolescents, São Paulo, Brazil, Revista Brasileira de Epidemiologia 2010;13:457-467.

23. Jacob JA, Nair MKC. Protein and micronutrient supplementation in complementing pubertal growth. Indian J Pediatr. 2012;79(Suppl 1):S84-91.

24. Souza RAG, Yokoo EM, Sichieri R, Pereira RA. Energy and macronutrient intakes in Brazil: results of the first nationwide individual dietary survey. Public Health Nutr. 2015;18:3086-95.

25. Sardinha AN, Canella DS, Martins APB, Claro RM, Levy RB. Dietary sources of fiber intake in Brazil. Appetite. 2014;79:134-8.

26. Food and Agriculture Organization of the United Nations (FAO). (2020). FAOSTAT. http://www.fao.org/faostat/en/\#data/QC/visualize (Accessed, 2021-04-07)

\section{Publisher's Note}

Springer Nature remains neutral with regard to jurisdictional claims in published maps and institutional affiliations.

Ready to submit your research? Choose BMC and benefit from:

- fast, convenient online submission

- thorough peer review by experienced researchers in your field

- rapid publication on acceptance

- support for research data, including large and complex data types

- gold Open Access which fosters wider collaboration and increased citations

- maximum visibility for your research: over $100 \mathrm{M}$ website views per year

At BMC, research is always in progress.

Learn more biomedcentral.com/submissions 